Jurnal Geocelebes Vol. 1 No. 1, April 2017, 1 - 4

\title{
ANALISIS RAWAN BENCANA LONGSOR MENGGUNAKAN METODE AHP (ANALIYTICAL HIERARCHY PROCESS) DI KABUPATEN TORAJA UTARA
}

\author{
Azaliatul Hidayah ${ }^{1}$, Paharuddin ${ }^{1 *}$, Muh. Altin Massinai ${ }^{1}$ \\ ${ }^{I}$ Program Studi Geofisika, Fakultas Matematika dan Ilmu Pengetahuan Alam \\ Universitas Hasanuddin Makassar \\ *Penulis koresponden. Alamat email: fardin@ @sci.unhas.ac.id
}

\begin{abstract}
Abstrak
Penelitian ini bertujuan menentukan faktor utama penyebab longsor di Kabupaten Toraja Utara. Parameter yang digunakan yaitu elevasi, kemiringan lereng, aspek lereng, geologi, tekstur tanah, kelurusan, jarak dari jalan, jarak dari sungai, curah hujan dan penutupan lahan. Penelitian ini menggunakan metode AHP (Analytical Hierarchy Process). Berdasarkan hasil penelitian faktor utama penyebab terjadinya longsor adalah parameter curah hujan dengan bobot 0.317 , kemudian tekstur tanah, jarak dari jalan, jarak dari sungai, geologi, penutupan lahan, kelurusan, kemiringan lereng, aspek lereng dan parameter yang memperoleh bobot terkecil yaitu elevasi dengan bobot 0.027 .
\end{abstract}

Kata Kunci : Faktor utama, longsor, AHP (Analytical Hierarchy Process), Toraja Utara

\begin{abstract}
The purpose of this research is to determine the main factor that causing landslides in North Toraja District. They are several parameters used to adjust the landslides at that area i.e. elevation, slope, geology, soil texture, alignment, distance from the road, distance from the river, rainfall and land cover. This research uses the AHP (Analytical Hierarchy Process) method to show a factor dominated causing landslides. The results show that the main factors causing the landslide are rainfall with the weight factor is 0.317 , following by soil texture, distance from the road, distance from the river, geology, and land cover is about 0.027 .
\end{abstract}

Keywords: Main factor, landslide, AHP (Analytical Hierarchy Process), North Toraja

\section{Pendahuluan}

Kabupaten Toraja Utara merupakan daerah yang rawan akan longsor dengan zona potensi gerakan tanah menengah hingga tinggi. Longsor yang terjadi mengakibatkan beberapa korban jiwa, kerusakan rumah, hingga putusnya jalur transportasi darat antar kecamatan. Dalam penelitian ini metode AHP digunakan untuk menentukan faktor utama yang menyebabkan terjadinya longsor..

\section{Longsor}

Gerakan tanah ialah segala perubahanperubahan yang dialami muka bumi akibat 
pengaruh gaya Tarik bumi (gravitasi) disebabkan rayapan tanah dan longsoran tanah. Pada lereng-lereng pegunungan sering terjadi gerak yang lambat menuju ke arah lembah. Gerak ini terjadi jika musim penghujan. Daerah-daerah yang ditumbuhi pohon-pohon akan miring ke arah lembah. Seperti yang terjadi di daerah Lengkese di Sulawesi Selatan, dimana pohon terlihat miring di lembah Bawakaraeng. Contoh lain dapat dilihat di Maribaya Lembang Jawa Barat. Pohon-pohon yang tumbuh pada deretan bukit- bukit sebelah selatan (sesar Lembang) sebagian besar miring ke arah lembah karena rayapan tanah (Katili dan Marks, 1963 dalam Massinai, 2015).

\section{Analytical Hierarchy Process (AHP)} Metode AHP (Analytical Hierarchy Process) dikembangkan oleh Thomas L. Saaty pada tahun 70-an di Warston school. Metode AHP merupakan salah satu metode yang digunakan dalam sistem pengambilan keputusan. Penyelesaian masalah dengan AHP terdapat beberapa prinsip dasar, yaitu penguraian (decomposition), perbandingan berpasangan (comparative judgement), sintesa prioritas (synthesis of priority) dan konsistensi logis (logical consistency).

AHP memanfaatkan persepsi pakar atau informan yang dianggap ahli sebagai input utamanya sehingga diperoleh bobot dari masing-masing parameter atau kriteria yang digunakan dalam penelitian.

\section{Metode Penelitian}

Secara geografis daerah penelitian dibatasi koordinat $02^{0} 05^{\prime}-03^{0} 05^{\prime}$ LS dan $119^{0} 45^{\prime}$ $120^{\circ} 02^{\prime}$ BT. Kabupaten Toraja Utara merupakan pemekaran dari Kabupaten Tanah Toraja, dimana merupakan dataran tinggi yang dikelilingi oleh pegunungan dengan keadaan lerengnya curam yakni rata-rata kemiringannya diatas $25 \%$ (Cahyono dan Rustandi, 2015).

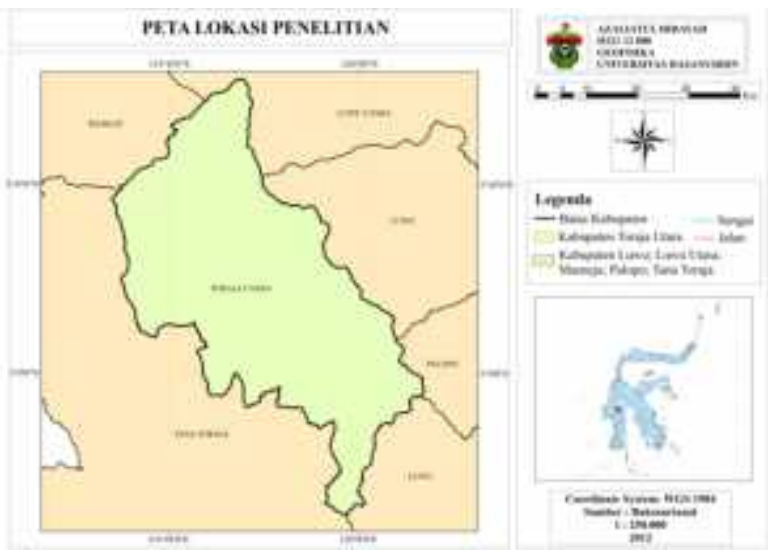

Gambar 1. Peta Lokasi Penelitian

Pengumpulan data penelitian dilakukan dengan pemberian kuesioner kepada responden. Kuesioner yang digunakan mengandung beberapa parameter kerawanan longsor. Parameter kerawanan longsor yang digunakan yaitu; elevasi, kemiringan lereng, aspek lereng, geologi, tekstur tanah, kelurusan, jarak dari jalan, jarak dari sungai, curah hujan dan penutupan lahan. Parameter ini akan dibuat suatu klasifikasi berdasarkan referensi atau sesuai dengan atribut peta. Perbandingan berpasangan dibuat dengan membandingkan klasifikasi yang telah ditentukan, lalu penentuan bobot dilakukan oleh responden dengan kriteria yaitu pihakpihak yang dianggap mengetahui dan memahami karakteristik wilayah penelitian, khususnya peneliti yang berhubungan dengan tanah longsor di Kabupaten Toraja Utara.

\section{Hasil dan Pembahasan}

Parameter Penyebab Longsor

1. Curah hujan yang tinggi lebih banyak menghasilkan debit air, sehingga dapat menyebabkan tanah kedap air.

2. 2Tekstur tanah turut menentukan tata air dalam tanah, yaitu berupa kemampuan tanah untuk meloloskan 
air, kecepatan infiltrasi, penetrasi dan kemampuan pengikatan air oleh tanah.

3. Jarak dari sungai, semakin dekat lereng dengan sungai maka semkin besar peluang untuk terjadinya longsor hal ini disebabkan oleh tingkat kejenuhan air pada lereng secara langsung berpengaruh pada stabilitas lereng.

4. Jarak dari jalan dapat menyebabkan terjadinya longsor hal ini disebabkan oleh lalu lintas kendaraan disekitar lereng. Longsor tidak langsung terjadi tetapi berproses awalnya jalan yang dilalui kendaraan mengalami retakan yang jika dibiarkan lama-lama akan longsor.

5. Geologi adalah salah satu parameter yang digunakan dalam penelitian tanah longsor, hal ini disebabkan oleh perbedaan satuan unit litologi akan berbeda kerentanannya terhadap tanah longsor.

6. Penutupan lahan dapat menyebabkan terjadinya longsor yaitu berupa tubuh air hal ini disebabkan oleh lahan yang berair kurang kuat mengikat butir tanah dam membuat tanah menjadi lembek dan jenuh air sehingga mudah terjadi longsor.
7. Kelurusan marupakan salah satu faktor penyebab terjadinya longsor, hal ini disebabkan oleh semakin tinggi kerapatan kelurusan, maka tingkat pelapukan batuan induk semakin intensif dan mengurangi kuat geser dari material penyusun lereng akibat diskontinuitas dan sekaligus menyebabkan infiltrasi air yang tinggi.

8. Kemiringan lereng berpengaruh terhadap terjadinya longsor, jika hujan tinggi maka panjang lereng meningkat disertai dengan meningkatnya erosi

9. Aspek lereng memiliki pengaruh terhadap terjadinya longso, hal ini disebabkan oleh penerimaan sinar matahari secara langsung yang mengakibatkan tanah pembentuk lereng menjadi kering, yang apabila musim hujan tiba maka air akan masuk kedalam rongga tanah yang tebuka bila sudah terisi penuh dapat mengakibatkan longsor dan erosi tanah.

10. Elevasi berpengaruh terhadap terjadinya longsor, hal ini disebabkan oleh ketinggian lereng bergantung pada kemiringan lereng atau besarnya sudut lereng

Tabel 1. Matrik Berpasangan

\begin{tabular}{|c|c|c|c|c|c|c|c|c|c|c|}
\hline \multicolumn{11}{|c|}{ Matriks Berpasangan } \\
\hline Tujuan & E & KL & At & G & $\pi$ & $\mathbf{K}$ & IDJ & IDS & $\mathrm{CH}$ & PI \\
\hline E & 1 & 2 & 2.289428 & 4.379519 & 5.593445 & 1.44225 & 3556893 & 3.556893 & 6,804092 & 2.289428485 \\
\hline $\mathbf{K L}$ & 05 & 1 & 1 & 3.914868 & 4.217163 & 1.817121 & 2.466212 & 2.466212 & 4.610436 & 0.843432665 \\
\hline AL & 0.4368 & 1 & 1 & 3 & 4.217163 & 1.44225 & 2.620741 & 2.620741 & 6.257325 & 1 \\
\hline 6 & 0.2283 & 0.25544 & 0.333333 & 1 & 3 & 0.584804 & 1.587401 & 1. 587401 & 4.121285 & 0.693361274 \\
\hline$\pi$ & 01788 & 0.23713 & 0.237126 & 0.333333 & $I$ & 0.584804 & 1.44225 & 1.44225 & 2.466212 & 0.693361274 \\
\hline $\mathrm{K}$ & 0.6934 & 055032 & 0,693361 & 1.709976 & 1.709976 & 1 & 3 & 3.979057 & 6.257325 & 1.44224957 \\
\hline JDS & 02811 & 0.40548 & 0.381571 & 0.629961 & 0.693361 & 0.333533 & 1 & 1817121 & 6.082202 & 0.480749857 \\
\hline IDS & 0.2811 & 0.40548 & 0.381572 & 0.629961 & 0.693361 & 0.251315 & 0550321 & 1 & 4.326749 & 0.480749857 \\
\hline $\mathrm{CH}$ & 0147 & 0.2169 & 0159813 & 0242643 & 0.40548 & 0159813 & 0164414 & 0.23112 & 1 & 0.522757959 \\
\hline PL & 0.4368 & 128563 & 1 & 1.44225 & 1.44225 & 0.693361 & 2.080084 & 2.080084 & 1912931 & 1 \\
\hline JUMLAH & 4.1833 & 725637 & 7.476205 & 17.28251 & 22.9722 & 8.30905 & 18.46832 & 20.78088 & 43.83856 & 9.446090942 \\
\hline
\end{tabular}




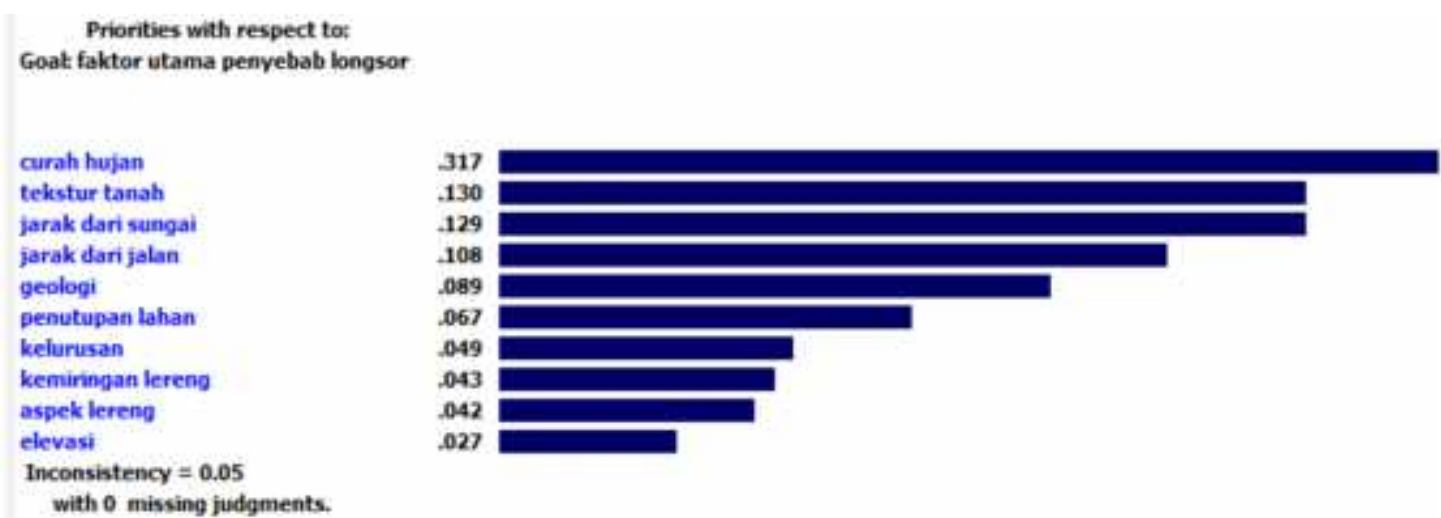

Gambar 2. Grafik hasil pembobotan parameter penyebab longsor

\section{Kesimpulan}

Faktor utama penyebab terjadinya bencana longsor di Kabupaten Toraja Utara adalah curah hujan berdasarkan hasil dari ketiga responden, curah hujan memiliki bobot yang tertinggi yaitu 0,317 . Hal ini disebabkan oleh curah hujan yang tinggi lebih banyak menghasilkan debit air sehingga tanah kedap air, dan parameter yang memperoleh skor terkecil adalah elevasi dengan bobot 0,027 hal ini disebabkan oleh ketinggian lereng bergantung pada kemiringan lereng atau besarnya sudut lereng..

\section{Daftar Pustaka}

Badan Geologi. "Tanggapan Bencana Gerakan Tanah" diakses 19 Sep 2016. www.vsi.esdm.go.id.

Bakosurtanal. 2012. Peta Rupa Bumi

Digital Indonesia Skala 1:25.000.

http://www.bakosurtanal.go.id/peta-

rupabumi.

Cahyono, E. B. dan Rustandi, U. 2015. Penyelidikan Batubara Daerah Palangi Dan Sekitarnya Kabupaten Toraja Utara, Provinsi Sulawesi Selatan. http://psdg.geologi.esdm.go.id/kolokium /2015/efos/4.pdf

Heryani, R. 2014. Analisis Kerawanan Banjir Berbasis Spasial Menggunakan Analytical Hierarchy Process (AHP) Kabupaten Maros. Skripsi. Fakultas
Matematika dan Ilmu Pengetahuan Alam Universitas Hasanuddin Makassar.

Massinai, M. A. 2015. Geomorfologi Tektonik. Pustaka Ilmu Group. Yogyakarta. 